Jpn. J. Limnol., 47, 3, 2392 246, 1986.

\title{
Vertical Distribution of Phytoplankton in a Stratified Lake (Lago Dom Helvecio, Southeastern Brazil) with Special Reference to the Metalimnion.
}

\author{
K. Hino, J. G. Tundisi and C. S. Reynolds
}

\begin{abstract}
Deep maxima of several species of phytoplankton were found to occur in the metalimnion of Lake D. Helvecio, during a period of strong thermal stratification, at depths receiving very low intensities of incident radiation.

The vertical distributions of ${ }^{14} \mathrm{C}$ assimilation and of the photosynthetic pigment, chlorophyll $a$, were investigated to explain the possible causes for the metalimnetic accumulation of biomass.
\end{abstract}

Key words : phytoplankton, metalimnion maxima, chlorophyll.

\section{Introduction}

As has been recognized in various limnological studies, the mass occurrence ("bloom") of certain species of phytoplankton in the surface water of many lakes is generally considered to reflect their artificial chemical enrichment, particularly with nitrogen and phosphorus. Many of the organisms involved, especially the cyanobacteria Microcystis, Aphanizomenon and Anabaena, have been studied intensively in an attempt to discern the nature of the interactions between their physiological adaptations and the environmental factors that influence their rates of cellular growth.

While instances of large planktonic biomasses occurring near the surface are more common among eutrophic systems, many temperate lakes show a different pattern of vertical distribution. Shortly after the lakes become thermally stratified in sum. mer, certain organisms accumulate in the metalimnion, some meters below the water surface. This applies especially to species of the genus Oscillatoria, such as $O$.rubescens, O. agardii and O. mougeotii (REyNolds and WaLsby, 1975 ; WatANabe, 1979 ; Konopka, 1982). Comparable behavior of cyanobacteria in a tropical lake has been reported recently by REYNOLDS et al. (1983), who described a metalimnetic maximum of the cyanobacterium Lyngbya cf. limnetica in Lake Carioca (Minas Gerais, Brazil) and who suggested that such vertical distributions are by no means confined to temperate waters.

The capacity of cyanobacteria to regulate their vertical position and remain at selected depths is supposedly dependent upon a delicate control of the buoyancy imparted by the production of intracellular gas-vacuoles through their dilution by cellular growth and through collapse of the weaker constituent gas-vesicles under increasing turgor-pressure (WALSBY, 1978). That in some cyanobacterial populations, loss of buoyancy occurs at such low light intensities and with an inadequate increase in cell turgor to collapse gas-vesicles suggests the existence of some additional mechanism of buoyancy regulation (WALSBY et al., 1983).

Accumulations of phytoplankton at certain depth may have other causes. KIEFER et al. (1972) found the maximum standing-crop in Lake Tahoe, U. S. A., to be below the euphotic zone. They attributed to passive sinking of cells from productive subsurfaces as the cause of accumulation in deep water.

Such biological stratifications also influence the lake metabolisms through, for example, the changes in the rate of nutrient regeneration in the epilimnion and consequently in primary production (TUNDISI, 1983).

The present work describes possible causes of phytoplankton stratification in Lake D. Helvecio.

\section{General features of Lake D. Helvecio}

The lake is located (Lat. : $19^{\circ} 10^{\prime} \mathrm{S}$ and Long. : $\left.42^{\circ} 10^{\prime} \mathrm{W}\right)$ in a depressional area of the River Doce Valley, inside the Parque Florestal do Rio Doce, and original primary tropical forest ("Mata Atlântica") now replaced by dense secondary forest. The climate is constantly warm, with a seasonal difference 
of 5 to $7^{\circ} \mathrm{C}$ and mean temperatures ranging from 20 to $22^{\circ} \mathrm{C}$. Lake D. Helvecio is one of the biggest and deepest lakes in the system, presenting a dentritic shape. Its surface area is $6.9 \mathrm{~km}^{2}$, with a perimeter of $36 \mathrm{~km}$, a maximum depth of $30 \mathrm{~m}$, a mean depth of $12.1 \mathrm{~m}$, and a total volume of $381.495 \times 10^{5} \mathrm{~m}^{3}$ (Tundisi and MusarRa, in press).

\section{Material and methods}

This study was carried out between 28 February and 4 March 1981. Field measurements and samples were obtained at station I of Tundisi et al. (1981). Water temperatures were measured in situ $\left( \pm 0.1^{\circ} \mathrm{C}\right)$ using a Toho Dentan ET3 thermistor. The penetration of photosynthetically-active radiation was determined directly with a $\mathrm{Li}^{-}$cor submersible quantum sensor (Lambda Instruments). A submersible selenium photocell, equipped with interchangeable filters (Chance Bros. and Schott), was used to measure the penetration of light in discrete spectral blocks ("blue", 350-500 nm : OB10 ; "green", 500-650 nm : OGR1 ; and "red”, 650-750 nm : RG9). Water samples for chemical analysis were collected from selected depths in a two liter Van Dorn Bottle. Millipore-filtrates were used to determine the concentrations of ammonium, nitrate and nitrite nitrogen and also orthophosphate phosphorus, following the standard methods described in MACKERETH et al. (1978). The same samples were used in titrimetric determinations of dissolved oxygen concentrations, following the modified Winkler technique of POMER OY and KIRSCHMAN (1945). Conductivity and $\mathrm{pH}$ were measured directly. Carbon dioxide concentrations were calculated from appropriate equations given in MACKERETH et al. (1978).

Samples for the analysis of the phytoplankton were separately obtained for selected depths, using a suction pump. One liter aliquots were vacuum -filtered through glass-fiber filters (Whatman $\mathrm{GF} / \mathrm{C}$ ) which were then frozen $\left(-20^{\circ} \mathrm{C}\right)$ for later extraction (in $90 \%$ acetone) and spectrophotometric determination of chlorophyll concentration, following the procedure described by GolTERMAN (1969).

The phytoplankton, in fresh $100-\mathrm{ml}$ aliquots, was gently concentrated through netting (apertures $>58$ $\mu \mathrm{m}$ ) and immediately fixed in Lugol's solution, for counting the principal species of "net plankton" using the sedimentation and inverted microscope technique of Lund, Kipling and LE CREN (1958).

Primary production of the phytoplankton was determined in field exposures by the ${ }^{14} \mathrm{C}$-fixation method, as described by VOLLENWEIdER (1974).

\section{Results}

The series of temperature profiles (Fig. 1) showed that there was a well-defined temperature structure in Lake Dom Helvecio throughout the observation period. The water column at Station $\mathrm{I}\left(Z_{\max } \simeq 30 \mathrm{~m}\right)$ was divisible into three layers of approximately equal depth. The epilimnion $\left(\simeq 31^{\circ} \mathrm{C}\right)$ and hypolimnion $\left(\simeq 24.9^{\circ} \mathrm{C}\right)$ were separated by a mean metalimnetic temperature gradient of $-0.6^{\circ} \mathrm{C} \cdot \mathrm{m}^{-1}$.

The penetration of photosynthetically-active radiation is represented in Fig. 2A. The solar energy reaching the upper and lower metalimnetic boundaries was equivalent to 24.5 and $0.5 \mu \mathrm{E} \cdot \mathrm{m}^{-1}$, respectively. Taking the depth of the euphotic zone $\left(Z_{\mathrm{eu}}\right)$ as the depth reached by $1 \%$ of the irradiance obtained immediately beneath the surface $\left(\mathrm{I}_{0}=880 \mu\right.$. $\left.\mathrm{E} \cdot \mathrm{m}^{-2} \cdot \mathrm{sec}^{-1}\right)$, it clearly exceeded the maximum depth of isothermal mixing $\left(Z_{\mathrm{m}}\right)$ during the study period.

The lowest coefficient of vertical extinction occurred in the "blue" spectral block (350-550 nm) : 1\% was estimated to reach $18.2 \mathrm{~m}$ (Fig. 2B). The contemporary Secchi-disk reading was $8.7 \mathrm{~m}$.

The variation with depth in the concentration of dissolved inorganic nitrogen $\left(\mathrm{NH}_{4}^{+}-\mathrm{N} ; \mathrm{NO}_{3}^{-}-\mathrm{N}\right.$ and $\mathrm{NO}_{2}^{-}-\mathrm{N}$ ) and phosphorus (see Fig. 3) reflects the strong thermal stability of the lake. Ammonium levels, especially, increase towards the bottom of the metalimnion from 16 to $500 \mu \mathrm{g} \mathrm{N} \cdot 1^{-1}$, where there was also a sharp decrease in the dissolved oxygen content (Fig. 4a) . The hypolimnion was virtually anoxic. The highest $\mathrm{CO}_{2}$ value was found at $20 \mathrm{~m}$ depth and conductivity values increased below $17 \mathrm{~m}$ (Figs. $4 \mathrm{~b}$ and $4 \mathrm{c}$ ). However, little fluctuation in $\mathrm{pH}$ with respect to depth was detected (Fig. 4d).

Assimilation ${ }^{14} \mathrm{C}$ by the phytoplankton community is represented by curve $\mathrm{A}$ in Fig. 5b. The depth profile of carbon fixation shows the classical near -surface photoinhibition and sub-surface peak in photosynthetic rate (at about $2 \mathrm{~m}$ depth). Further peaks in the metalimnion can be related partly to the activities of heterotrophic organisms (up to $58 \%$ of the total assimilation occurred in the dark (Fig. 5a) and partly to the relatively much higher concentrations of chlorophyll that were encountered in the lower metalimnion (Fig. 6).

Expressed per unit of chlorophyll, the depth distri. bution of carbon-fixation showed a more typical profile ( $B$ in Fig. 5b), decreasing from the measured 


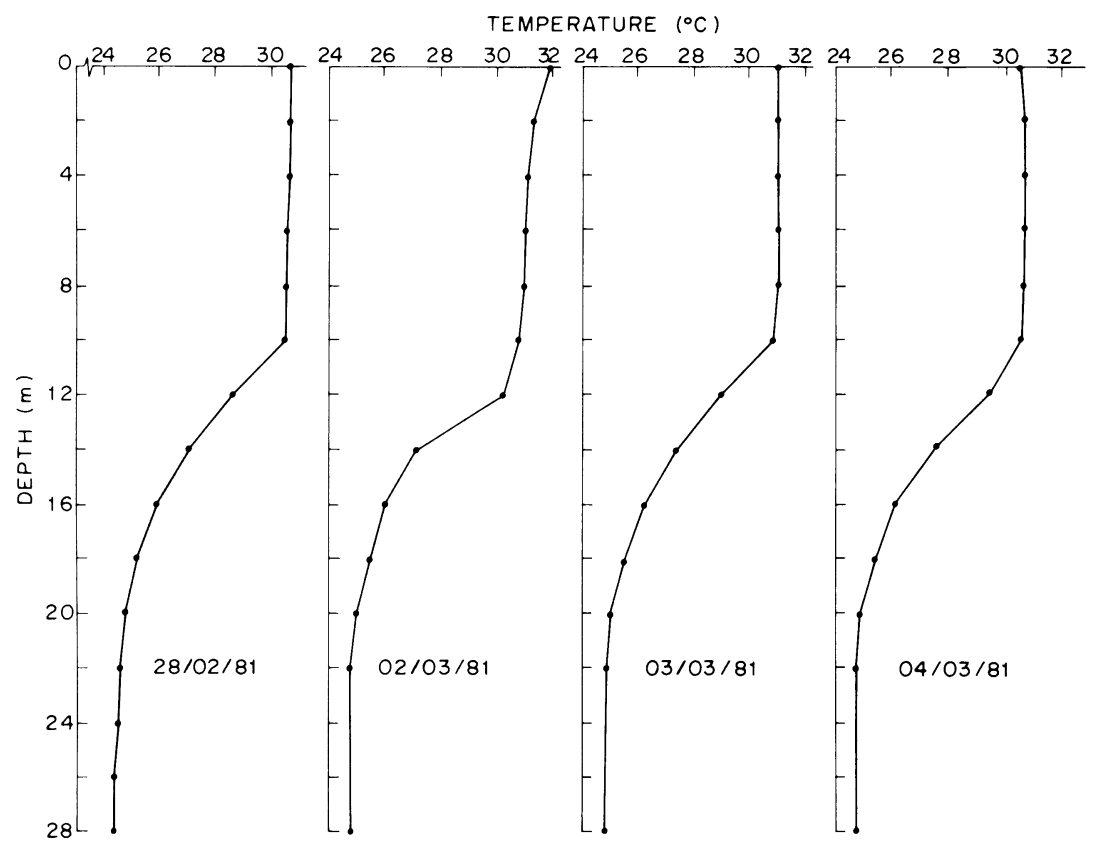

Fig. 1. Depth profiles of water temperature in four days in Lake D. Helvecio; measurements made between 11:00 and 13:00.
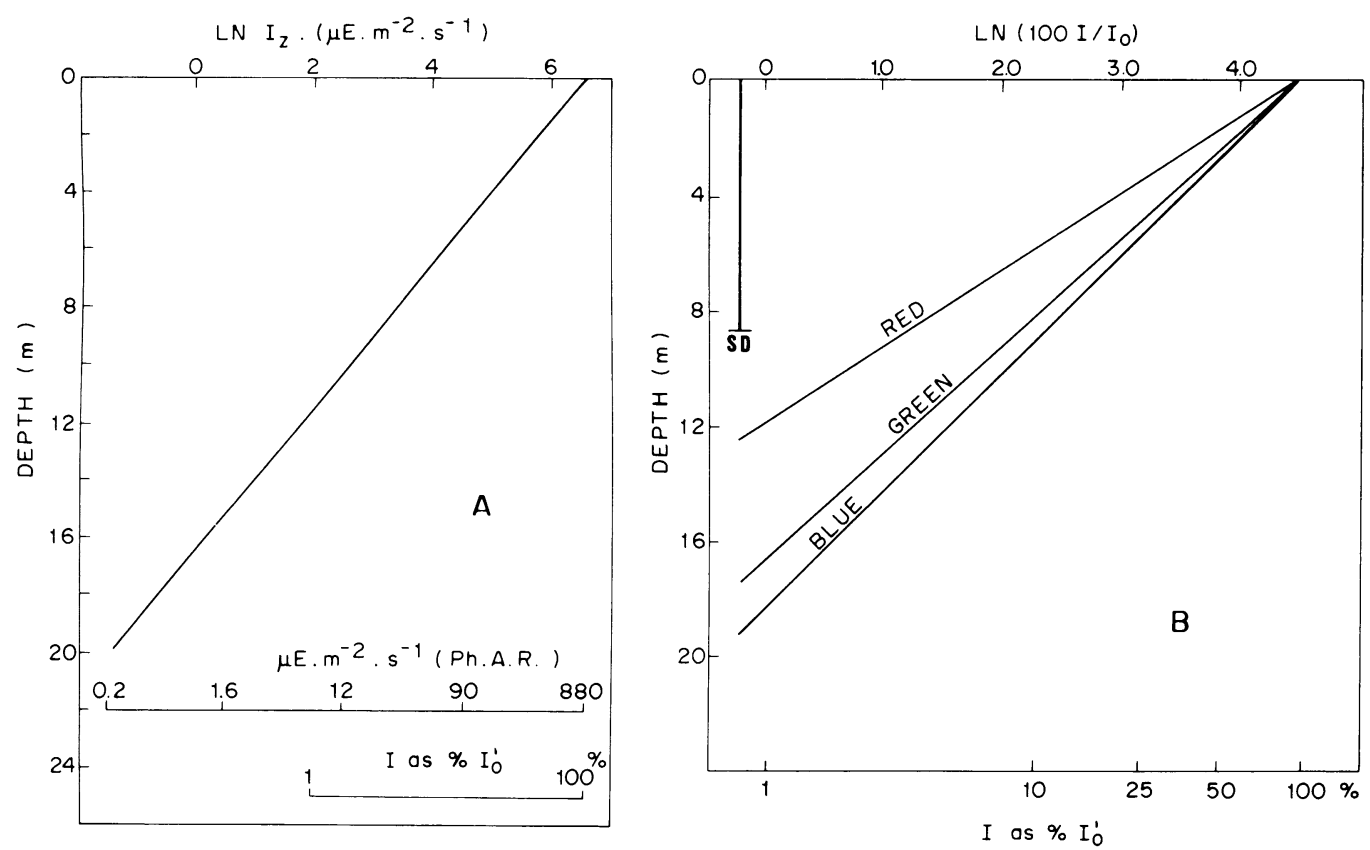

Fig. 2. Penetration of total photosynthetically active spectral (A) and of selected spectral (B); blue, green and red; plotted on a logarithmic scale, in Lake D. Helvecio; measurements made between 11:00 and 13:00. 

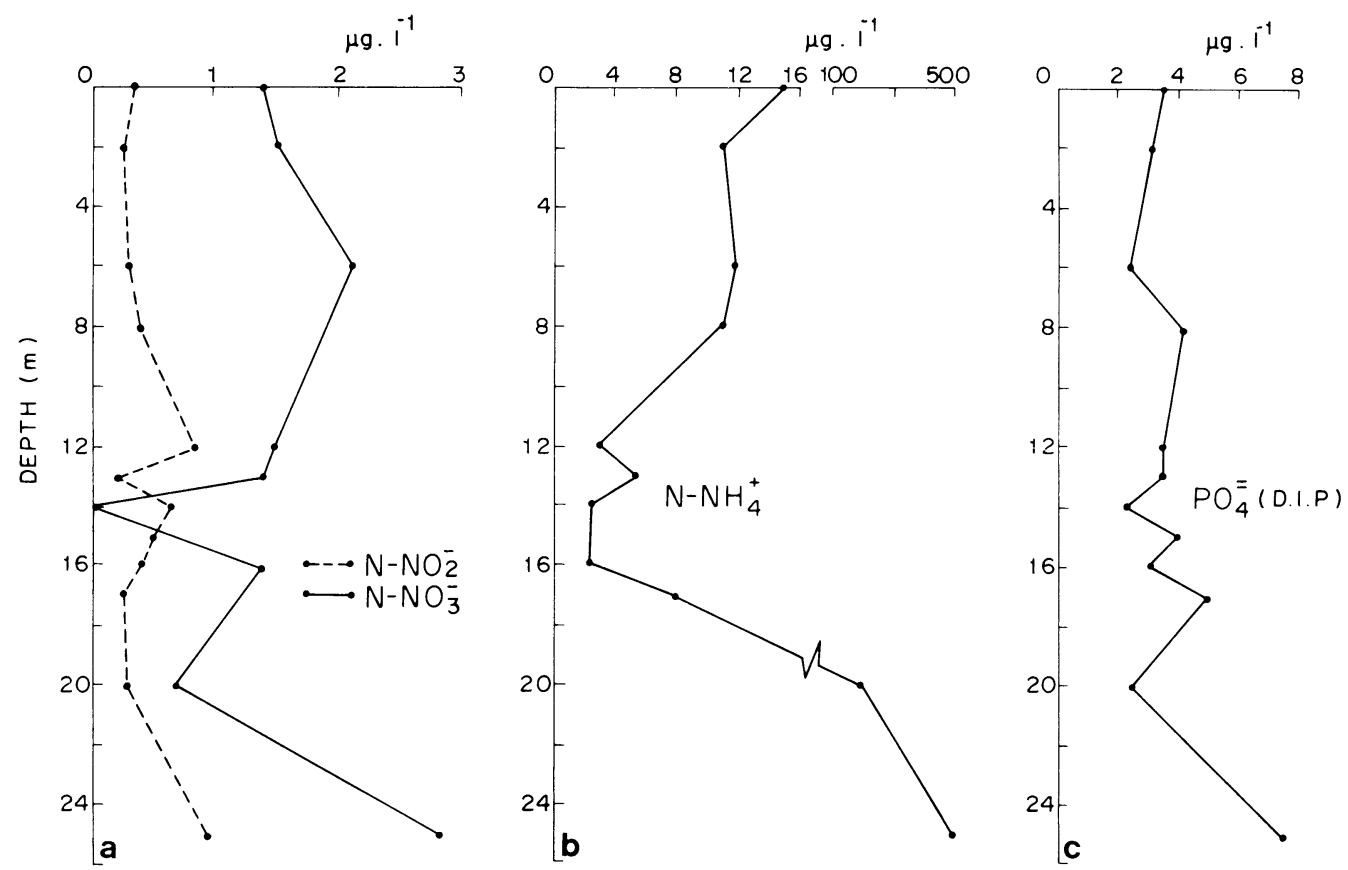

Fig. 3. Depth profiles of dissolved inorganic nutrients; $\mathrm{N}-\mathrm{NO}_{3}{ }^{-}, \mathrm{N}-\mathrm{NO}_{2}{ }^{-}$(a), $\mathrm{N}-\mathrm{NH}_{4}{ }^{+}$(b), and $\mathrm{P}-\mathrm{PO}_{4}^{3-}$ (PID)(c) in Lake D. Helvecio (3 March 1981)
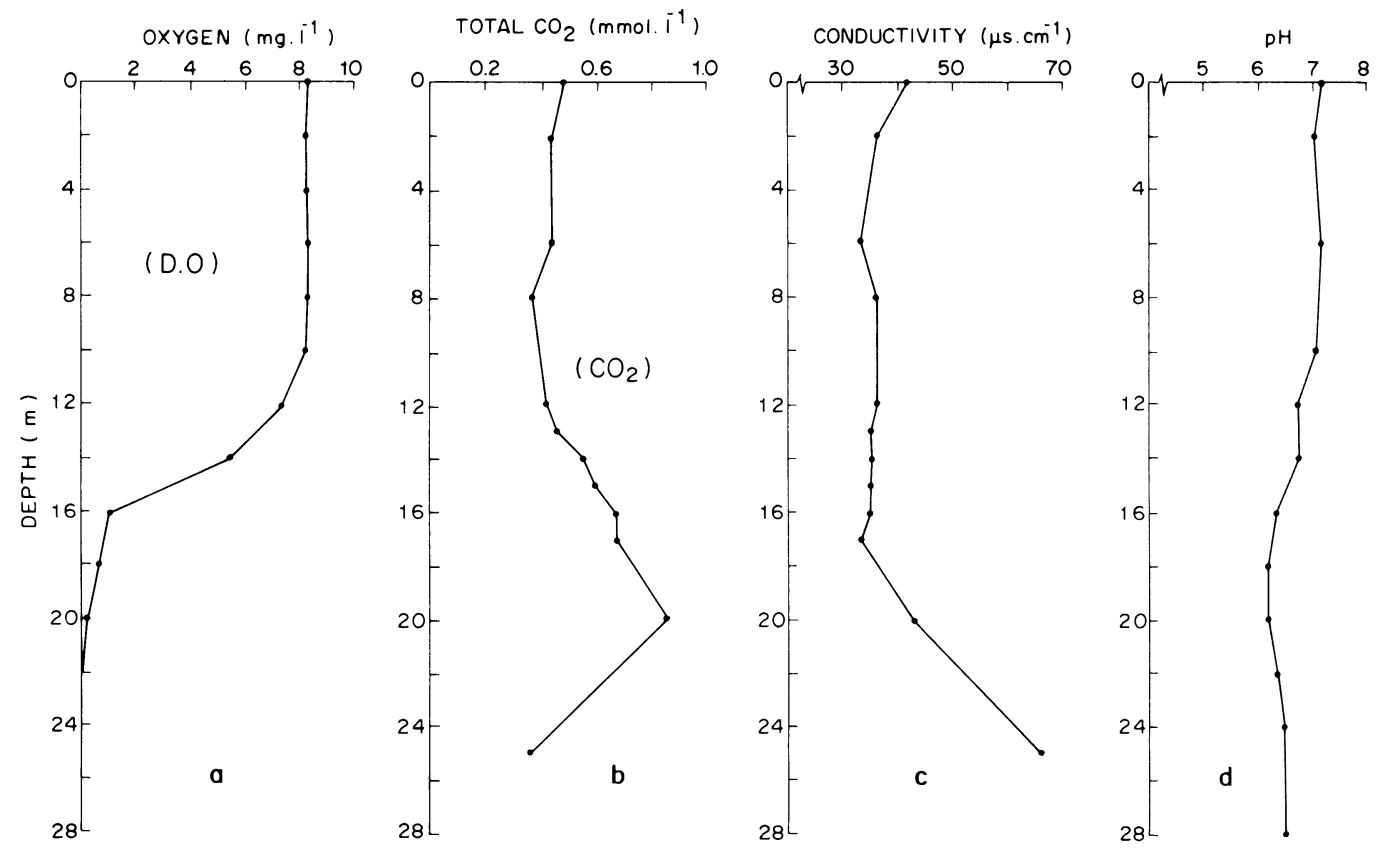

Fig. 4. Depth distributions of various environmental factors: oxygen concentration (a): total carbon dioxide concentration (b): $\mathrm{pH}$ (c): and conductivity in Lake D. Helvecio (3 March 1981). 

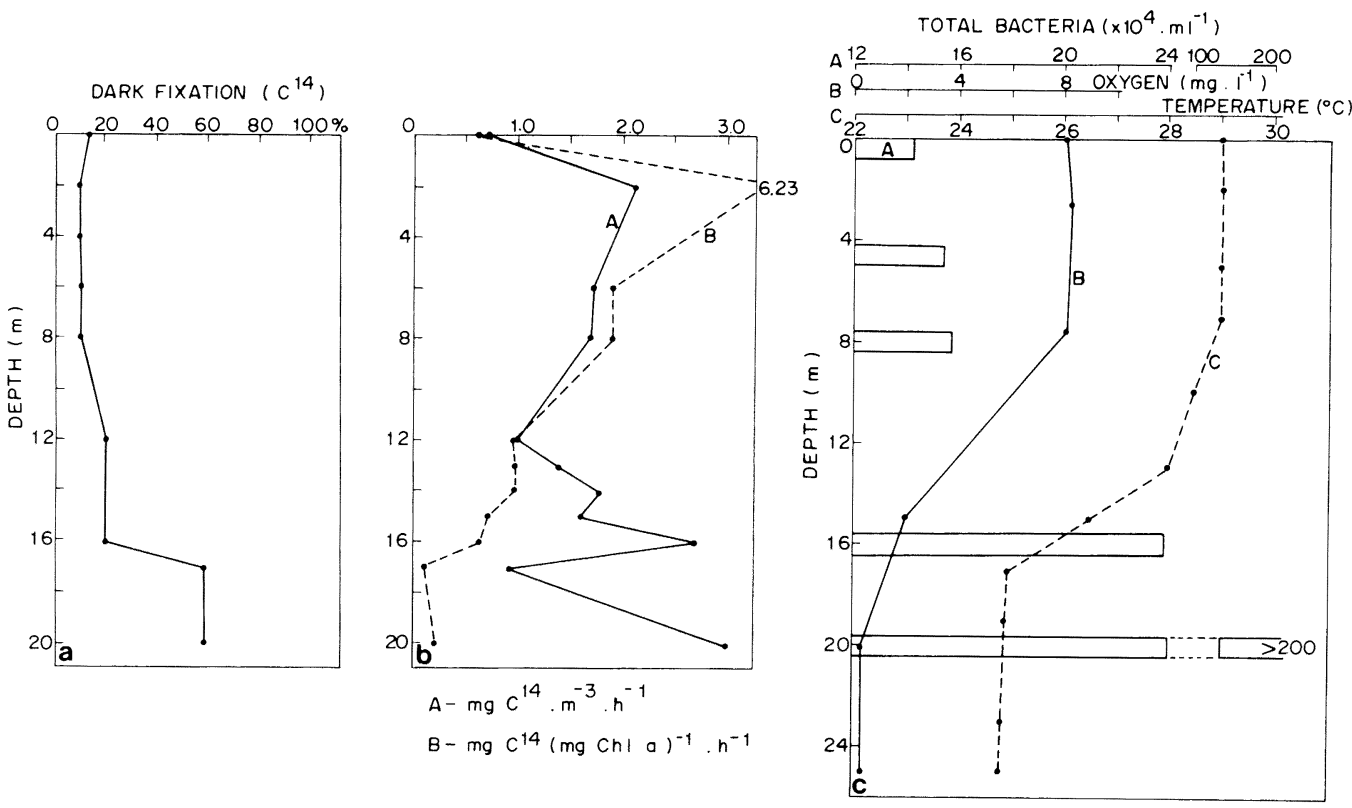

Fig. 5. (a) Vertical distribution of $\mathrm{C}^{14}$ uptake $\left(\mathrm{mgC} \cdot \mathrm{m}^{-3} \cdot \mathrm{hr}^{-1}\right)$ and specific photosynthetic rate (mgC $(\mathrm{mg} \cdot \mathrm{Chl} a)^{-1} \cdot \mathrm{hr}^{-1}$ ) in Lake D. Helvecio (3 March 1981). (b) Vertical distribution of dark assimilation rate in Lake D. Helvecio (3 March 1981). (c) Depth distributions of total bacteria in stratified period in Lake D. Helvecio (data from Rugani (1980)).

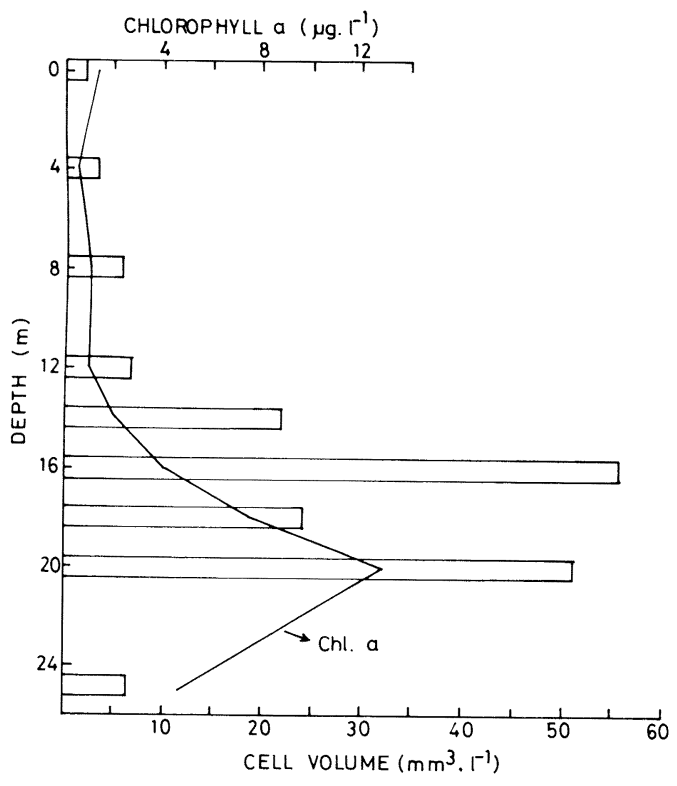

Fig. 6. Vertical distribution of chlorophyll $a$ and "net plankton" cell volume in Lake D. Helvecio (3 March 1981).

maximum of $6.23 \mathrm{mgC}(\mathrm{mg} \mathrm{Chl} a)^{-1} \cdot \mathrm{hr}^{-1}$ at $\simeq 2$ to 0.1 $\mathrm{mgC}(\mathrm{mg} \mathrm{Chl} a)^{-1} \cdot \mathrm{hr}^{-1}$ in the lower metalimnion.
However, the data do not suggest a unifrom direct relationship between photosynthetic rate and light extinction; rather, there is an indication of enhanced photosynthetic efficiency at depth (shown in Table 1).

This observation adds interest to the vertical distribution of the photosynthetic populations themselves and the extent of their adaptation to low light intensities.

The total volume of "net plankton" occurring at various depths in Lake D. Helvecio showed good general agreement with the vertical distribution of chlorophyll (Fig. 6), with clear evidence of an accumulation of algal biomass in the lower metalimnion. The distribution of the more abundant individual component species (shown in Fig. 7), however; revealed two distinct and contrasting patterns. Many of the desmid species present (Staurastrum spp.) were each distributed more or less uniformly through the epilimnion with localized increases in abundance within the metalimnion. The concentration of representative cyanobacteria (Microcystis, Lyngbya and Spirulina) showed a relatively stronger tendency towards a primarily metalimnetic distribution, with their peak abundances located within the depth range of $16-20 \mathrm{~m}$. 
Table 1. Vertical distribution of relative photosynthetic light utilization rate at various depths in Lake D. Helvecio.

\begin{tabular}{cc}
\hline Depth $(\mathrm{m})$ & $\mathrm{mgC}(\mathrm{mg} \mathrm{Chl} a)^{-1} \cdot \mathrm{E}^{-1} \cdot \mathrm{m}^{-2}$ \\
\hline 2 & 7.2 \\
8 & 13.5 \\
12 & 21.5 \\
14 & 38.4 \\
16 & 50.8 \\
\hline
\end{tabular}

\section{Discussion}

The present observations of Lake D. Helvecio, made over several consecutive days in summer, give a clear indication of persistent thermal stratification and a highly stable metalimnion. In turn, this stability is a major influence on the distribution of biomass, energy flux and material cycling in the lake. Localized accumulations of phytoplankton biomass in stable layers of the water column are of common occurrence in oligotrophic lakes (KIEFER et al., 1972 ; Moll and STOCKNER, 1982). In Lake D. Helvecio, not only was a major proportion of the planktonic biomass confined to the stable metalim. nion but also several species of cyanobacteria were located principally within this part of the water column. Moreover, the metalimnion was the site of almost half (equivalent to $185.5 \mathrm{mg} \mathrm{C} \cdot \mathrm{m}^{-2} \cdot \mathrm{d}^{-1}$ ) the total measured carbon fixation $\left(377.3 \mathrm{mg} \mathrm{C} \cdot \mathrm{m}^{-2} \cdot \mathrm{d}^{-1}\right)$ in the whole water column, despite lowered specific productivity $\left(4.28 \mathrm{mg} \mathrm{C}(\mathrm{mg} \mathrm{Chl} a)^{-1} \cdot \mathrm{d}^{-1}\right)$ under poor conditions of irradiance occurring there. This fixation is not exclusively attributable to autotrophic production, since between 10 and $58 \%$ of measured fixation occurred in the dark, through microbial biosynthesis (Fig. 5a and 5c). Similar ratios of dark total fixation (10-40\%) have been reported from some meromictic lakes in Japan (TAKAHASHI et al., 1970). Taking the mean value $(40 \%)$ for the metalimnion of Lake D. Helvecio, the photosynthetic carbon fixation for the layer would account for some $111.3 \mathrm{mg} \mathrm{C} \cdot \mathrm{m}^{-2} \cdot \mathrm{d}^{-1}$, equivalent to a specific photosynthetic rate of $\simeq 2.57 \mathrm{mg} \mathrm{C} \cdot(\mathrm{mg} \mathrm{Chl} a)^{-2} \cdot \mathrm{d}^{-1}$. The contribution of phytoplankton in the metalim. nion to the formation of organic carbon in the whole column thus represents $\simeq 11.5 \%$. However, the two metalimnetic assimilation peaks detected (Fig. 5b) may be separately associated with the production of either phytoplankton and bacteria, the lower $\geqq 20 \mathrm{~m}$ recalling the deepwater, subphotic fixation in Lake Tahoe, U.S. A., that PAERL and Goldman (1972) attributed to bacterial activity, while the upper (14 $-16 \mathrm{~m}$ ), around the base of the euphotic zone, may be more directly related to accumulated photosynthetic biomass.

The specific rate of photosynthesis (expressed per unit of chlorophyll) even at this depth is nevertheless, severely limited by the low light levels obtaining, whereas the insolate in the epilimnion sustains relatively much more rapid rates of $\mathrm{C}$ fixation. The
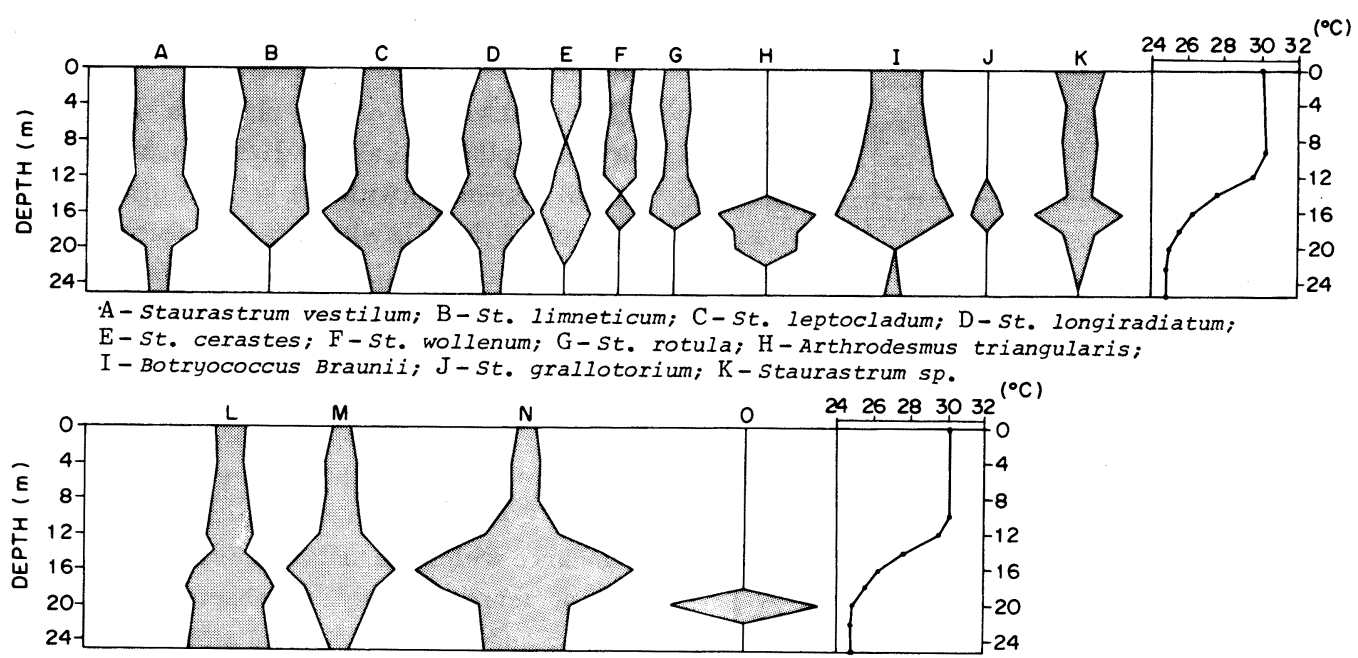

L-Microcystis wenserbergii; M-Microcystis aeruginosa; $\mathrm{N}$ - Lyngbya Birgeii;
$\mathrm{O}-$ Spirullina Nordstedtii

Fig. 7. Vertical distribution of main net phytoplankton in Lake D. Helvecio (3 March 1981). 
question arises whether such a distribution of planktonic biomass is caused by the physiological adaptation or is the consequence of passive sedimentation from the epilimnion. The latter explanation may well apply to the desmid distribution represented in Fig. 7, which organisms have no known mechanism for controlling vertical position and are supposedly reliant upon near-surface turbulence to maintain them in suspension. On the other hand, many of the cyanobacteria which were found to have accumulated selectively in the metalimnion are able to regulate their buoyancy and, hence, supposedly are capable of regulating vertical station (REYNolds and WALsBy, 1975; REYNolds, 1978). That the present instance of apparent stratification had some permanence is indicated by the degree of low-light adaptation of photosynthesis detected at this depth. Thus, although we made no observations on diel variations in vertical distribution, there are reasonable grounds for supposing that the cyanobacteria, Microcystis aeruginosa, Microcystis Wensenbergii, Lyngbya Birgeii, and Spirulina Nordstedii were at least roughly stratified in the metalimnion throughout the observation period. A corresponding vertical distribution of L. limnetica was demonstrated in the nearby Lake Carioca (REynolos et al., 1983). A deep chlorophyll maxima at Lake D. Helvecio was already described by Tundisi et al. (1981 (op. cit.)).

It must also be supposed that this pattern of distribution confers some selective advantage to the survival and maintenance of the species in Lake D. Helvecio. Certainly it is within this region that photoautotrophs could have access to supplies of dissolved inorganic nitrogen that were relatively unavailable in the epilimnion (Fig. 3). It might therefore be hypothesized that the cyanobacteria maintained vertical positions that alone simultaneously satisfied both requirements (light, nutrients) for autotrophic growth. However, without more information on the temporal changes in the populations concerned, this remains speculative, and further investigations are required. For the present, however, these observations furnish additional evidence that, in suitably stable tropical lake systems, cyanobacteria are not only able to stratify at depth, much as they do in some temperate lakes, but they maintain stationary under lower light intensities. The existence of an additional buoyancy regulating mechanism that would function under low-light conditions is again indicated (cf. WALSBY et al.,
1983 ; REYNOLDS et al., 1983).

\section{摘 要}

\section{ブラジル成層湖における植物プランクトンの鉛直分布}

ブラジル南東部の水深 $30 \mathrm{~m}$ のオドセ湖で成層期 に中層で植物プランクトンおよびクロロフィルの現存 量の最大が観測された。この層は, 水温躍層の下層で 弱光を受ける場所であるが, このプランクトンは, こ の層に蓄積したものであろう。

\section{Acknowledgments}

The authors are grateful to Dr. Takako Matsumura-Tundisi, Mr. João Gomes da Silva, Mrs. Marina P. Santilli, Mrs. Juçara Codá and Mr. Takahashi Hatanaka for technical assistance in the field and in the laboratory. We also thank the Forest Institute of Minas Gerais State for laboratory facilities and accommodation at the field site, Conselho Nacional de Pesquisas (Grant number 22220137/75) for financial support and the Organization of American State who funded CSR's visit to Brazil. (Project : Ecology and Limnology of Lakes and Reservoirs in Brazil). The financial support of FAPESP (Proc. no. 80/0173-7) is also gratefully acknowledged.

\section{References}

Beardall, J., and I. Morris (1975) : Effects of environmental factors on photosynthesis patterns in Phaeodactylum tricornutum (Bacillariophyceae) II. Effect of oxygen. J. Phycol. 11 : 430-434.

Cullen, J. J. (1982): The deep chlorophyll maximum : comparing vertical profiles of chlorophyll $a$. Can. J. Fish. Aquat. Sci. 39 : 791-803.

Golterman, H. L. (1969): Methods for chemical analysis of freshwaters. IBP Handbook No. 8. Blackwell, Oxford.

Kiefer, A. D., O. Holm-Hansen, C. R. Goldman, R. Richards and T. BERMAN (1972) : Phytoplankton in Lake Tahoe: Deep-Living Populations. Limnol. Oceanogr. $17:$ 418-422.

KonOPKA, a. (1982): Physiological ecology of a metalimnetic Oscillatoria rubescens population. Limnol. Oceanogr. 27,: 1154-1161.

Lund, J. W. G., C. Kilpling and E. Le CRen, (1958) : The inverted microscope method of estimating algal numbers, and the statistical basis of estimation by counting. Hydrobiologia, 11:43 -70 .

Mackereth, F. J. H., J. Heron and J. F. Talling 
(1978): Water analysis: Some revised methods for limnologists. Sci. Publs. Freshwat. Biol. Ass. No. 36 .

Moll, R. A. and F. E. Stockner (1982) : A hypothesis relating trophic status and subsurface chlorophyll maxima of lakes. Arch. Hydrob. 94(4) : 425 -440 .

PaErl, H. and H. C. Goldman (1972): Heterotrophic assays in the detection of water masses at Lake Tahoe, California. Limnol. Oceanogr. 17: 145 -148 .

Pomeroy, R. and M. D. Kirschman (1945) : Determination of dissolved oxygen : proposed modification of the Winkler method. Ind. Engng. Chem. Analyt. Edn. $17: 715-716$.

REyNolds, C. S. (1978) : Stratification in natural population of bloom-forming blue-green algae. Verh. Int. Verein. Limnol. $20: 2285-2292$.

REYNOLDS, C.S. (1978) : Interrelations of photosynthetic behavior and buoyancy regulation in a natural population of a blue-green alga. Freshwat. Biol. $5:$ 323-338.

Reynolds, C. S., J. G. Tundisi and K. Hino (1983) : Observations on a metalimnetic Lyngbya population in a stably stratified tropical lake (Lagoa Carioca, Eastern Brazil). Arch. Hydrobiol. 97 : 7 -17 .

Reynolds, C. S. and A. E. Walsby (1975): Water Blooms. Biol. Rev. 50 : 437-481.

Rugani, C. A. (1980): Bacterias amonificantes e fatores ecológicos nos Lagos Carioca e D. Helvecio (Vale do Rio Doce, MG). Master thesis Univ. Federal de São Carlos, SP. 168pp.

SmaydA, T. J. (1970) : The suspension and sinking of phytoplankton in the sea. Oceanogr. Mar. Biol. Ann. Rev. $8: 353-414$.

TAKahashi, M., Y. Yamaguchi and S. Ichimura (1970) : Dark fixation of $\mathrm{CO}_{2}$ in the lake with special reference to organic matter production. Bot. Mag. Tokyo, 83 : 397-410.

Tundisi, J. G. (1983) : A review of basic ecological processes interacting with production and stand. ing-stock of phytoplankton in lakes and reservoirs in Brazil. Hydrobiologia, 100 : 223-243.

Tundisi, J. G., T. Matsumura-Tundisi, M. C. Pontes and J. G. Gentil (1981) : Limnological studies at quarternary lakes in eastern Brazil. Primary production of phytoplankton and ecological factors at lake D. Helvecio. Rev. Bras. Bot. 4:5-14.

Tundisi, J. G. and M. L. Musarra : Morphometric characteristics of four lakes in the Rio Doce valley system. Ciéncia e Cultura (in press).

Vollenweider, R. A. (1974) : A Manual on Methods for Measuring Primary Production in Aquatic Environments. IBP Handbook No. 12. Blackwell, Oxford.

Walsby, A. E. (1978): The gas vesicle of aquatic prokaryontes. p. 327-335. In : R. Y. STAINER et al. (eds.) Relations between Structure and Func. tion in the Prokaryotic Cell. Cambridge University Press.

Walsby, A. E., H. C. Uthilen and I. J. Johnsen (1983) : Buoyancy changes of a red-coloured Oscillatoria agardhii in Lake Gjersjoen, Norway. Arch. Hydrobiol. 97 : 18-38.

Watanabe, M. F. (1979) : Studies on the metalimnetic blue-green alga Oscillatoria mougeotii in a eutrophic lake with special reference to its population growth. Arch. Hydrobiol. 98:66-86.

（著者：Kozo Hino* and José G. Tundisi**, Laboratory of Limnology, Department of Biological Sciences, Federal University of São Carlos, 13560, S. Carlos, SP, Brazil; Colin S. Reynolds, Freshwater Biological Association, Ambleside, Cumbria, LA22 OLP, UK. Present address *: Electronote, Centrais Electricas do Norte do Brasil SA, SCN. Quadra 6. Conj. A, B1. B, Sala 1201, Supercenter Venacio 3000. CEP 70710, Brasilia, DF., Brazil, **: Department of Hydraulic, School of Engineering, University of São Paulo, CEP 13560, S. Carlos, SP., Brazil)

Received: 9 August 1985 Accepted : 1 April 1986 